\title{
The Difference of the Attitude Towards Money Among Adult Mongolians
}

\author{
Tumendemberel Purev \\ National University of Commerce and Business, Ulanbator, Mongolia
}

\begin{abstract}
The study presents the attitude towards money among adult Mongolians. The research focused on differences of the attitude towards money related to age, gender, and employment in Mongolian people. The aim of this study was to examine the differentiation of the attitude towards money of adult Mongolians related to satisfaction with life, the sense of security, and the role of socio-demographical parameters, such as age, gender, and employment. People's attitudes towards money seem to be acquired through education, professional experience, and monetary habits. People perceived money as a symbol of a sense of security, a marker of achievement or status, and the source of worry or anxiety. Researchers noted that money has a multi-dimensional psychological meaning. The research sample consisted of Mongolian people: A group of 300 Mongolians. The age of participants varied from 21 to 60 years old. Statistical Version 10.0 was used to analyze the data. The results showed that the attitude towards money depends on the satisfaction with life, the sense of security, and were different by gender and employment. Mongolians have strong tendencies to use money as a symbol of power and status. However, this tendency is stronger in the group of men in comparison to women, in this culture. Retention-Time was bigger differentiated by variable employment. According to the results, there was no significant difference in age. Furthermore, there were negative association between satisfaction with life and distrust in the group. They who have financial worry seem to be less satisfied with their life. The most number of people in Mongolian sample evaluated own income as average. The percentages of personal professional activity were the highest than another category in the group. The results of statistical analysis showed that differences of frequencies of some components of economic security were significant in the sample. In sum, our study will contribute to knowledge about the importance of general life satisfaction and feeling security on the attitude toward money. The results may be useful to create the program of economic education and program that will change attitude toward money. The results provide information about the cultural difference. The knowledge may be useful for better understanding other nations and integrating people from different cultures.
\end{abstract}

Keywords: attitude towards money, age, gender and employment, satisfaction with life, sense of security

\section{Introduction}

Money is the instrument of commerce and the measure of value (Smith, 1776/1937). However, it also has a multidimensional psychological meaning. The psychological meaning of money is related to people's perceptions of money and their behaviors (Fank, 1994; Furnham, 1984; Tang, 1992, 1993; Tang \& Gilbert,

Tumendemberel Purev, Ph.D., senior lecturer, Department of the Natural and Social Science, National University of Commerce and Business. 
1995; Yamauchi \& Templer, 1982, Gąsiorowska, 2013; Wąsowicz-Kiryło, 2013, Górnik-Durose, 2016). Money also can be treated as a symbol of status, prestige, power, and worth (Yamauchi \& Templer, 1982).

In our study, we focused on attitude towards money. Generally, an attitude is a pre-disposition to respond in particular ways towards specific things, objects (Myers, 2004). It has three main elements:

1. A belief or opinion about something;

2. Feelings about that thing;

3. A tendency to act towards that thing in certain ways.

People's attitudes towards money seem to be acquired through education, professional experience, and monetary habits (Furnham \& Argyle, 1998; Wąsowicz-Kiryło, 2013).

People's attitudes towards money are learned through the socialization process, established early in childhood, and maintained in adult life (Kirkcaldy \& Furnham, 1993; Gąsiorowska, 2007). The money attitudes (MAs) may reflect previous life experiences (Furnham, 1984; Wernimont \& Fitzpatrick, 1972). Furthermore, people's attitudes towards money are really a summary of their life experiences in the past. These different attitudes are acquired through an individual's primary and secondary socialization processes, parents' income, education, social class, beliefs, child-rearing practices, and monetary habits (Furnham, 1984). The degree to which people value money is correlated with economic development (Lynn, 1991). The attitudes towards money and towards the use of money may be influenced by demographic factors, such as age, gender, and employment, etc. Nowadays, modern society requires orientation in financial management and competence in management of one's own money.

The increasing number of requirements related to economic development of countries and the expectations of individuals related to the effectiveness of financial management are a challenge to education, including economic education and professional education (Paszkowska-Rogacz, 2015).

The dynamics of economic changes in Mongolia is very fast and have been taking place in a relatively short time. The pace and range of changes seem to create a context not fully understood by people. Many difficulties encountered by people are linked to money and its effective management. Psychological adaptation to these dynamic and far reaching changes in the socio-economic context seems to need time and support through changes in the socio-cultural context, including the policy and education system. This study of the attitudes towards money is the first step in the area of psychology of money in Mongolian psychology. The results of my research are significant to make the basis for educational program directed to creation economical consciousness in the Mongolian youth taking into account individual differences related to satisfaction with life, the sense of security, age, gender, and employment.

Mongolians developed economic thinking and feeling of savings of money, foods, and goods during the developmental stage of children. The reason is that they live far away from settled place or shops and Nomadic people purchase by wholesale to last for several months. However, for Mongolians, it is important to know that the products they buy will preserve quality in the long time use. Children that follow their parents' behavior through observations provide a good example of future life.

The study focused on the psychological determinant of attitudes towards money, such as satisfaction with life and the sense of security in Mongolian group. The study also made it possible to comprehend more fully the role of socio-demographic parameters, such as age, gender, and employment in determining attitudes towards money in Mongolians. The basic task in this paper is to describe the attitudes towards money of Mongolians. 
Novelty of this study will provide new knowledge about the importance of the impact of satisfaction with life and the sense of security on the attitude towards money, which will be useful for economic education in the culture. The study of the attitude towards money in Mongolia will make the basis for creating programs to develop an awareness of the profits and dangers related to different attitude towards money.

\section{Theoretical Fundamentals for Own Research}

\section{Definition of the Attitude Towards Money}

Scholars say that attitude can be defined as "a tendency to act in a favorable or unfavorable way towards an object" (Eagly \& Chaiken, 1993). In the author's study, the thesis accepted that the attitude towards money is a summary of life experiences in the past. The different attitudes are learned through an individual's primary and secondary socialization process, parents' income, education, child-rearing practices, and monetary habits (Kirkcaldy \& Furnham, 1993). Methodological basis of the study is psychological concepts of Yamauchi and Templer (1982) related to attitudes toward money.

Yamauchi and Templer (1982) identified five MA dimensions (anxiety, distrust, power-prestige, quality, and retention-time). People who endorse Money Attitude Scale (MAS)-power-prestige view money as a symbol of success and a tool to gain power over their environment and others. They use it to impress others, seek status, and gain recognition. Money quality focuses on beliefs about money as a tool to acquire "the good life". Money retention-time is concerned with the conservation of money through budgeting, self-control, delay of gratification, and pursuit of parsimony and utilitarian consumption. Money distrust concerns hesitancy, doubt, and suspicion in money situations. Money anxiety focuses on money as a source of anxiety and protection from money situations.

Theoretical basis of the study are theories of social psychology and psychology of personality. The starting point is the theories of psychology of money. In this area, the important ideas related to money are embedded in the approach proposed by psychoanalysis theory, behaviorism, social learning theory, accentuation theory, and cognitive psychology.

According to behaviorism and learning theory, money should be interpreted as a generalized conditioned reinforcement (secondary reinforcement) which is associated with a variety of consumer goods and related to unconditioned reinforcement (Zaleśkiewicz, 2004; Wąsowicz-Kiryło, 2013).

\section{The Attitude Towards Money and Socio-Demographic Parameters}

The meaning of money is different for age and employment (Furnham, 1984; Dogan \& Torlak, 2014; Merchant, 2016).

The recent literature points out that age is an important factor in the formation of attitude towards money. Some researchers found that the younger participants had a higher tendency to see money as an indicator of status more than the older participants, who could be attributed to the fact that they spend more time in social occasions and they want to prove themselves in these occasions (Dogan \& Torlak, 2014; Merchant, 2016). In another study, older people were more worried about the future than younger people, because they had greater financial responsibility for families, children, and mortgages (Furnham, 1984). Elders valued most often photographs, but also furniture, books, and art. These objects gave them important the memories and they evoked together with links with the past, definition of self, and links with family (Csikszentmihalyi \& Rochberg-Halton, 1981). Belk (1991) said that elders interested in a few objects of importance to them. These 
are things which remind them of their past life and their relations with others. Although based on an American sample, Tang's (1992) study indicated that age and income are highly correlated to the factors of "evil" and "budget". The results presented that young people and people with lower incomes rated money as being more evil and were less concerned about the budgeting or management aspects of money.

Furthermore, employment is an important source of happiness, and it is the major source of money. Some jobs have to be paid, because they are unpleasant or dangerous, and indeed such jobs have to be paid more. For many people, their work is the most important thing in life. According to Wernimont and Fitzpatrick (1972), the employment status showed that employed groups view money much more positively, as desirable, important, and useful. The unemployed appeared to take a tense, worrisome, and unhappy view of money.

Earlier studies have pointed out that the attitudes towards money are differentiated by gender (Medina Saegert, \& Gresham, 1996; Gbadamosi \& Joubert, 2005; Bonsu, 2008). Significant differences related to gender were noted only in the dimension of power-prestige in the study. The result revealed that men in the group were more inclined to use money to impress and influence others, and as a symbol of success than women. These results are consistent with the data from psychological literature. Furnham and Argyle (1998) had found that men are obsessed with money especially for its power-prestige. Men are happier than women with their finances, and feel that they have control over their money (Rubinstein, 1980). Women are more careful with money. Compared to men, they show more concern for future financial security (Bailey \& Gustafson, 1991).

\section{The Attitude Towards Money and Satisfaction With Life}

Satisfaction with life refers to a cognitive judgmental process. The opinion of satisfaction depends on a comparison of an individual who must have money for feeling of satisfaction with life. Dyton and Kahneman (2010) described relationships between of personal income and satisfaction with life. If people have more money, they are not happy (as cited in Rubinstein, 1981). Janusz Czapiński (1991), analyzing the aspect of happiness, said that people are able to be happy, regardless of how they are doing and in what towards their lives are realized (Górnik-Durose, 2002). Pay satisfaction is influenced by other variables, for example, employees are more satisfied with their pay if they are satisfied in other ways as well (Weitzel, 1977).

\section{The Attitude Towards Money and Sense of Security}

Security is a condition of a person when he/she can satisfy basic needs for self-preservation and perception of being secured/psychologically/in the society (Zotova, 2011). Gąsiorowska (2014) wrote that high income might lead to lower level of financial worries. Also, having money reduces dependency on others, reducing anxiety in turn (Furnham, Wilson, \& Telford, 2012). In sum, security is defined as a subjective feeling of being safe whether one actually was or was not.

\section{Research Problem, Research Questions and Hypotheses}

\section{The Aims of Study}

The main aim of this study was to examine the attitude towards money of adult Mongolians related to satisfaction with life and sense of security.

The second aim of the study was to identify the differentiation in the attitude towards money by selected variables of age, gender, and employment in the cultural group. 


\section{Questions and Hypotheses}

Questions. The following research questions have been raised:

1. Is the attitude towards money differentiated by socio-demographic parameters, such as age, gender, and employment in Mongolian sample?

(a) Is the attitude towards money differentiated by age in Mongolian sample?

(b) Is the attitude towards money differentiated by gender in Mongolian sample?

(c) Is the attitude towards money differentiated by employment in Mongolian sample?

2. Is the attitude towards money dependent on satisfaction with life among Mongolians?

3. Is the attitude towards money dependent on sense of security among Mongolians?

Hypotheses. H 1 Attitude towards money is differentiated by socio-demographic parameters, such as age, gender, and employment in Mongolian sample.

H 1.1 Attitude towards money is differentiated by age in Mongolian people.

H 1.2 Attitude towards money is differentiated by gender in Mongolian people.

H 1.3 Attitude towards money is differentiated by employment in Mongolian people.

H 2 Attitude towards money depends on satisfaction with life in Mongolian sample?

H 3 Attitude towards money depends on sense of security in Mongolian sample?

\section{Research Methods}

Questionnaire methods were used in the study. One was a tool developed by Yamauchi and Templer (1982), MAS, the second tool was developed by Diener, Emmons, Larson, and Griffin (1985), Satisfaction With Life Scale (SWLS), the third tool was adults' sense of security questionnaire-Skala Poczucia Bezpieczeństwa Dorosłych (SBPD), by Department of Social Psychology and Studies on Adolescents in Poland (2014), and the fourth tool used questionnaire Q for collecting socio-demographic by author.

\section{Respondents}

The study consisted of a group of Mongolians. A total number of participants were 300, characterized by age (21-60 years old), gender, and employment.

\section{Analysis of Research Findings}

Quantitative analysis of the data gathered during the study was conducted. The analysis results are shown in the tables below.

\section{Verification of Hypothesis I}

The descriptive statistics for the variable of age in Mongolians are presented in Table 1.

Mean of power-prestige indicated higher than other mean in the scale MAS.

The reliabilities of the instruments were made using the Cronbach's alpha coefficient. The Cronbach's alpha coefficients indicate that value of reliability of dimensions of MAS whole was 0.88 . The differences of the dimensions were also analyzed. They are presented in Table 2.

Table 1

Descriptive Statistics of Variable Age

\begin{tabular}{lllll}
\hline Variables & Mean $N_{l}=300$ & Minimum & Maximum & $S D$ \\
\hline Age & 30.5 & 21.0 & 60.0 & 10.85 \\
\hline
\end{tabular}


Table 2

Psychometric Characteristics of the Scale MAS

\begin{tabular}{lllll}
\hline Variables & Mean & $S D$ & $\begin{array}{l}\text { Alpha } \\
\text { Cronbach in own study }\end{array}$ & Alpha Cronbach \\
\hline Overall & & & 0.88 & 0.77 \\
Power-prestige & 30.6 & 9.96 & 0.78 & 0.80 \\
Retention-time & 27.2 & 8.38 & 0.75 & 0.78 \\
Distrust & 23.7 & 8.09 & 0.75 & 0.73 \\
Quality & 19.8 & 5.36 & 0.67 & $/$ \\
Anxiety & 21.7 & 5.75 & 0.56 & 0.69 \\
\hline
\end{tabular}

It was expected that attitude towards money was differentiated by age in Mongolian group (H 1.1).

Table 3

Differences of the Attitude Toward Money by Variable of Age

\begin{tabular}{lllllll}
\hline variables & $\begin{array}{l}\text { Early adulthood } \\
N=200 / \text { Mean } /\end{array}$ & $\begin{array}{l}\text { Middle adulthood } \\
N=100 / \text { Mean/ }\end{array}$ & $U$ & $Z$ & $p$ & $r$ \\
\hline Power-prestige & 155.0 & 141.4 & $9,090.0$ & 1.2 & 0.19 & 0.12 \\
Retention-time & & 154.0 & $9,646.5$ & -0.4 & 0.61 & -0.02 \\
Quality & 155.9 & 139.6 & $8,916.0$ & 1.5 & 0.12 & 0.08 \\
Distrust & 153.7 & 144.0 & $9,352.5$ & 0.9 & 0.36 & 0.05 \\
Anxiety & 154.0 & 143.4 & $9,299.5$ & 0.9 & 0.32 & 0.05 \\
\hline
\end{tabular}

The results of statistical analysis show that the variable of age is not statistically significant in this study (see Table 3). So that Hypothesis H 1.1 was not verified among Mongolians.

According to the hypothesis H 1.2 was expected that attitude towards money is differentiated by gender in the group.

Table 4

Differences of Intensity of Components of Attitude Toward Money Related to Variable of Gender in the Sample

\begin{tabular}{|c|c|c|c|c|c|c|}
\hline & $\begin{array}{l}\text { Female } \\
N=187 \\
/ \text { Rank mean / }\end{array}$ & $\begin{array}{l}\text { Male } \\
N=113 \\
\text { /Rank mean/ }\end{array}$ & $U$ & $Z$ & $p$ & $r$ \\
\hline Power-prestige & 139.5 & 168.5 & $8,523.0$ & -2.80 & 0.01 & -0.16 \\
\hline RT & 154.4 & 143.8 & $9,819.5$ & 1.0 & 0.31 & 0.05 \\
\hline Quality & 146.9 & 156.4 & $9,894.0$ & -0.9 & 0.36 & -0.05 \\
\hline Distrust & 146.0 & 157.8 & $9,736.0$ & -1.1 & 0.25 & -0.06 \\
\hline Anxiety & 144.8 & 159.7 & $9,517.0$ & -1.4 & 0.15 & -0.08 \\
\hline
\end{tabular}

In Table 4, there is presented the result that the variable power-prestige is bigger differentiated the variable gender in the sample ( $r=-0.16$ in Mongolians). Men are more confident to use the money to impress and influence others and as a symbol of success than women in the group. The statistical analyses partly supported the hypothesis H 1.2.

The results show that among the Mongolians, retention-time was bigger differentiated by variable employment $(r=0.13)$. Other factors of MAS were not differed significance by the variable employment for the Mongolian sample. This result indicates that Mongolian people who have work perceived money as a means which give them security in the future more than unemployed people. So that, hypothesis $\mathrm{H} 1.3$ was partial confirmed for the Mongolians. 
It was expected that attitude towards money depends on satisfaction with life in Mongolian group (H 2).

Table 5

The Differences of Intensity of Components of Attitude Toward Money Related to Variable Employment in This Sample

\begin{tabular}{lllrlll}
\hline Variables & $\begin{array}{l}\text { Employment } \\
N=153\end{array}$ & $\begin{array}{l}\text { Unemployment } \\
N=147\end{array}$ & $U$ & $Z$ & $p$ & $r$ \\
& /Rank mean/ & /Rank mean/ & & & & \\
\hline Power-prestige & 153.3 & 147.5 & $10,816.5$ & 0.57 & 0.56 & 0.03 \\
Retention-time & 161.3 & 139.1 & $9,579.5$ & 2.21 & 0.03 & 0.13 \\
Quality & 148.2 & 152.8 & $10,845.0$ & -0.46 & 0.64 & -0.03 \\
Distrust & 145.3 & 155.8 & $10,454.0$ & -1.05 & 0.29 & -0.06 \\
Anxiety & 150.3 & 150.6 & $11,218.5$ & -0.03 & 0.97 & -0.002 \\
\hline
\end{tabular}

Table 6

Descriptive Statistics for Variables of General Satisfaction With Life

\begin{tabular}{|c|c|c|c|c|c|}
\hline Variable & Mean & $S D$ & Skewness & $\begin{array}{l}\alpha \\
\text { Cronbach } \\
\text { (own study) }\end{array}$ & $\begin{array}{l}\text { Original alpha } \\
\text { Cronbach }\end{array}$ \\
\hline SWLS & 21.96 & 4.61 & -0.20 & 0.75 & $\begin{array}{l}0.87 \\
\text { /Diener, 1985/ }\end{array}$ \\
\hline
\end{tabular}

The Cronbach's alpha coefficients calculated that the value of reliability of SWLS was 0.75 .

Table 7

Multiple Regression Summary for Dependent Variable: Power-Prestige, Retention-Time, Distrust, Quality, and Anxiety-Independent Variable: Satisfaction With Life-In the Group (Satisfaction With Life as Predictor of Attitude Towards Money

\begin{tabular}{|c|c|c|c|c|c|c|c|c|c|c|c|c|c|}
\hline \multirow{3}{*}{ Variable } & \multicolumn{3}{|c|}{ Power-prestige } & \multicolumn{3}{|c|}{ RT } & \multicolumn{3}{|c|}{ Distrust } & \multicolumn{2}{|r|}{ Quality } & \multicolumn{2}{|r|}{ Anxiety } \\
\hline & $B^{*}$ & $t(298)$ & $p$ & $B^{*}$ & $\begin{array}{l}t \\
(298)\end{array}$ & & $B^{*}$ & $t(298)$ & $p$ & $B^{*}$ & $T(298) p$ & $B^{*}$ & $t(298) p$ \\
\hline & -0.06 & -1.18 & 0.23 & 0.09 & 1.57 & 0.11 & -0.11 & -2.02 & 0.04 & -0.06 & $\begin{array}{ll}-1.09 & 0.27\end{array}$ & -0.09 & $\begin{array}{ll}-1.59 & 0.11\end{array}$ \\
\hline SWLS & \multicolumn{3}{|c|}{$\begin{array}{l}F(1,298)=1.399, p< \\
0.23, R^{2}=0.004\end{array}$} & \multicolumn{3}{|c|}{$\begin{array}{l}F(1,298)=2.491, p \\
<0.11, R^{2}=0.008\end{array}$} & \multicolumn{3}{|c|}{$\begin{array}{l}F(1,298)=4.101, p< \\
0.04, R^{2}=0.01\end{array}$} & \multicolumn{2}{|c|}{$\begin{array}{l}F(1,298)=1.197, p< \\
0.27, R^{2}=0.004\end{array}$} & \multicolumn{2}{|c|}{$\begin{array}{l}F(1,298)=2.532, p \\
<0.11, R^{2}=0.008\end{array}$} \\
\hline
\end{tabular}

Note. $R^{2}=0.004,0.4 \%$.

The results of multiple regression show that the associations between satisfaction with life and attitudes towards money in a group (see Table 7). According to the results of multiple regression, the strongest associations are between satisfaction with life and distrust $\left(\beta^{*}=-0.11, p<0.04\right)$ in Mongolian group.

Satisfaction with life is predictor of the attitudes towards money. Prediction of the attitude towards money by satisfaction with life is very limited.

Our findings established that satisfaction with life is statistically important for attitude towards money in the group. In Mongolian sample, satisfaction with life explains $0.4 \%$ variance of the attitudes towards money. The strongest prediction was noted for distrust $\left(R^{2}=0.01, p<0.04\right)$ in Mongolians.

Overall, the results of statistical analysis presented above partial confirm the hypothesis $\mathrm{H} 2$ which holds that the attitudes toward money among Mongolians depend on their satisfaction with life. 
Verification of hypothesis H 3 which holds that the attitudes towards money among Mongolians depend on sense of security.

A variable of sense of security consists of three aspects: attitude towards future, well-being, and sense of economic security. Variable of attitude towards future and variable of well-being represent quantitative category, but variable of sense of economic security — qualitative category.

Table 8

Descriptive Statistics of Variable of Sense of Security: Attitude Towards Future and Well-Being

\begin{tabular}{llll}
\hline Variable & Mean & $S D$ & $\begin{array}{l}\alpha \text { Cronbach } \\
\text { (Own research) }\end{array}$ \\
\hline Sense of security (overall) & $N=300$ & 2.67 & 0.60 \\
Attitude towards future & 4.82 & 0.67 & 0.62 \\
Well-being & 5.33 & 0.97 & 0.56 \\
\hline
\end{tabular}

The reliabilities of the instrument were made using the Cronbach's alpha coefficient. The Cronbach's alpha coefficients indicate that the values of reliabilities of sense of security, attitude towards future, and well-being were $0.60,0.62$, and 0.56 . The evaluations of income per-person in family in this culture are presented in Figure 1.

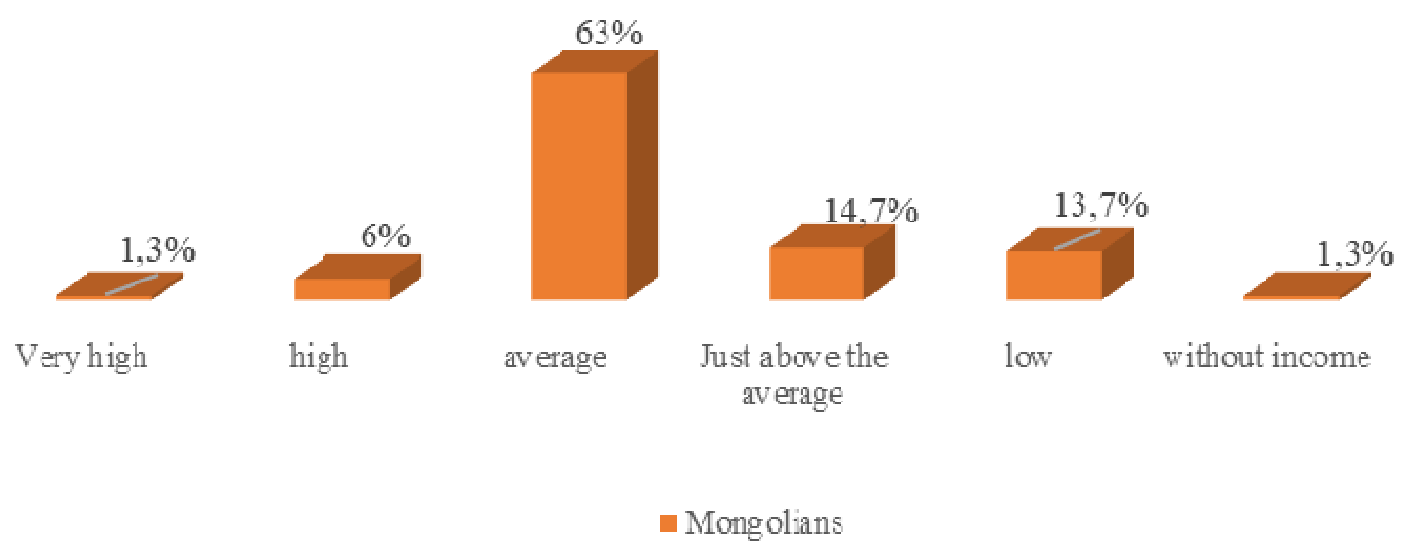

Figure 1. Distribution of frequencies of evaluations of income per-person in family in this culture.

The most number of people in Mongolian sample evaluated own income as average. However, the evaluation of income per-person in family was significant different in sample of Mongolians $\left(\chi^{2}=11.63, d f=5\right.$, $p<0.04)$.

The percentages of personal professional activity were the highest than another category in the sample. Domestic animals breeding and pasturing were lower percent of the source of living among Mongolians. The $\chi^{2}$ was significantly different of the source of living in the Mongolians.

Result of statistical analysis shows that difference of frequencies of the source of living among sample of Mongolians is significant $\left(\chi^{2}=34.92, d f=5, p<0.001\right)$ (see Figure 2). 


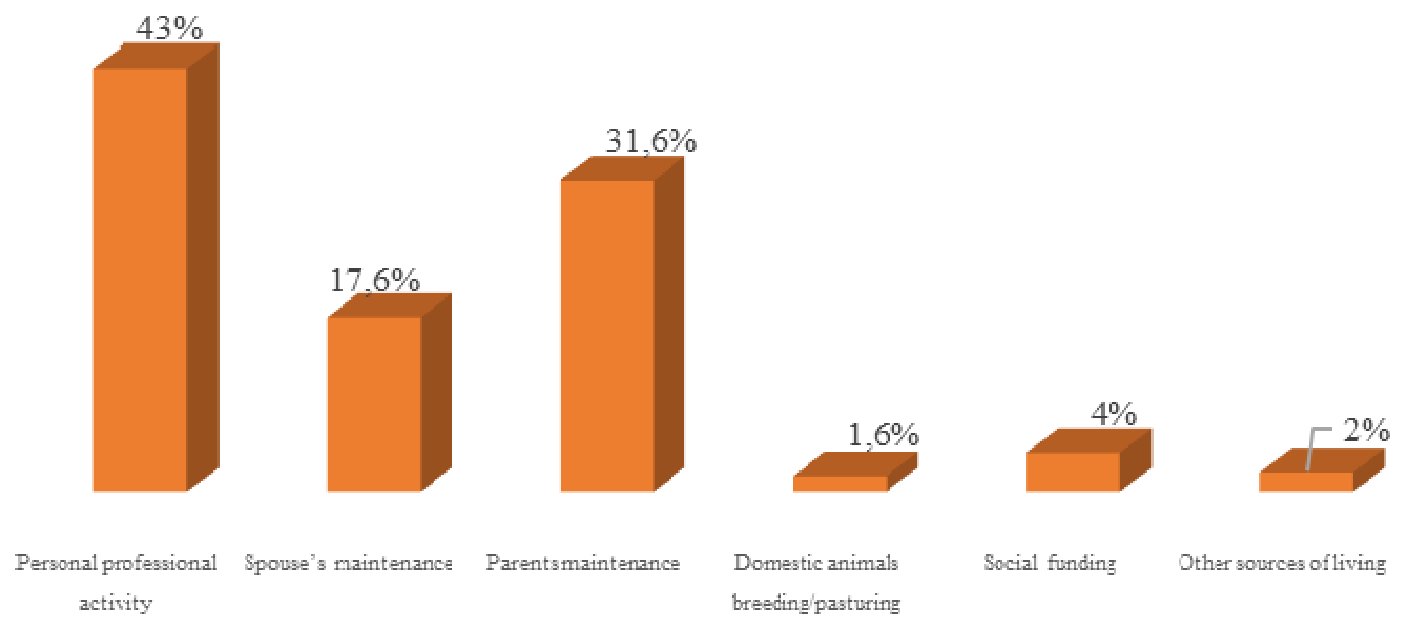

Figure 2. Distribution of frequencies of evaluations of indicated source of living in the group.

The results of statistical analysis showed that differences of frequencies of some components of economic security are significant in the samples. Significant differences are related to such components of sense of economic security as a regularity of income $\left(\chi^{2}=52.14, d f=1, p<0.001\right)$, possibility of changing job $\left(\chi^{2}=17.11, d f=1, p<0.001\right)$, risk of unemployment $\left(\chi^{2}=11.24, d f=1, p<0.001\right)$, and worries about security $\left(\chi^{2}=22.79, d f=1, p<0.001\right)$. Therefore, significant differences were noted for two categories related to debts to acquaintances and friends $\left(\chi^{2}=20.45, d f=1, p<0.05\right)$, and debts to family $\left(\chi^{2}=17.94, d f=1\right.$, $p<0.05$ ). In Mongolian sample, there are a higher percentage of people indicating the possibility of changing jobs, higher level of worries about security and more debts to acquaintances, friends, and family than others.

Table 9

Multiple Regression Summary for Dependent Variable: Power-Prestige, Retention-Time, Distrust, Quality, Anxiety; Independent Variable: Sense of Security (Attitude Toward Future and Well-being) -In the Group (Sense of Security as Predictor of Attitude Towards Money)

\begin{tabular}{|c|c|c|c|c|c|c|c|c|c|c|c|c|c|c|c|}
\hline \multirow{2}{*}{ Variables } & \multicolumn{3}{|c|}{ Power-prestige } & \multicolumn{3}{|c|}{ RT } & \multicolumn{3}{|c|}{ Distrust } & \multicolumn{3}{|c|}{ Quality } & \multicolumn{3}{|c|}{ Anxiety } \\
\hline & $B^{*}$ & $t(298)$ & $p$ & $B^{*}$ & $t(298)$ & $p$ & $B^{*}$ & $t(298)$ & $p$ & $B^{*}$ & $t(298)$ & $p$ & $B^{*}$ & $t(298)$ & $p$ \\
\hline \multirow{3}{*}{ ATF } & & -1.04 & 0.2 & -0.00 & -0.17 & & -0.17 & -2.98 & 0.00 & -0.06 & -1.0 & 0.29 & -0.13 & -2.39 & 0. \\
\hline & \multicolumn{3}{|c|}{$\begin{array}{c}F(1,298)=1.102, p< \\
0.29, R^{2}=0.26\end{array}$} & \multicolumn{3}{|c|}{$\begin{array}{c}F(1,298)=0.029, p< \\
0.86, R^{2}=0.001\end{array}$} & \multicolumn{3}{|c|}{$\begin{array}{c}F(1,298)=8.932, p< \\
0.05, R^{2}=0.02\end{array}$} & \multicolumn{3}{|c|}{$\begin{array}{c}F(1,298)=1.109 \\
p<0.29, R^{2}=0.003\end{array}$} & \multicolumn{3}{|c|}{$\begin{array}{l}F(1,298)=5.757 \\
p<0.01, R^{2}=0.01\end{array}$} \\
\hline & -0.02 & -0.40 & 0.68 & 0.06 & 1.15 & 0.25 & -0.13 & -2.29 & 0.02 & 0.06 & 1.09 & 0.27 & -0.10 & -1.74 & 0.08 \\
\hline \multirow[t]{2}{*}{ Well-being } & \multicolumn{3}{|c|}{$\begin{array}{c}F(1,298)=0.1680, p< \\
0.68, R^{2}=0.0005\end{array}$} & \multicolumn{3}{|c|}{$\begin{array}{c}F(1,298)=1.326, p< \\
0.25, R^{2}=0.004\end{array}$} & \multicolumn{3}{|c|}{$\begin{array}{c}F(1,298)=5.267, p< \\
0.02, R^{2}=0.01\end{array}$} & \multicolumn{3}{|c|}{$\begin{array}{c}F(1,298)=1.194 \\
p<0.27, R^{2}=0.003\end{array}$} & \multicolumn{3}{|c|}{$\begin{array}{l}F(1,298)=3.051, \\
p<0.08, R^{2}=0.01\end{array}$} \\
\hline & \multicolumn{3}{|c|}{$R^{2}=0.004,4 \%$} & \multicolumn{3}{|c|}{$R^{2}=0.005,5 \%$} & \multicolumn{3}{|c|}{$R^{2}=0.04,4 \%$} & \multicolumn{3}{|c|}{$R^{2}=0.01,1 \%$} & \multicolumn{3}{|c|}{$R^{2}=0.02,2 \%$} \\
\hline
\end{tabular}

Note. $R^{2}=0.004,0.4 \%$.

The results of statistical analysis show that in the Mongolian sample both aspects of sense of security (the attitude toward future and well-being) are significantly correlated only with one factor of the attitude towards money — distrust, and one aspect of sense of security—attitude toward future and anxiety (see Table 9).

In the Mongolian sample, the sense of security explains $0.4 \%$ variance of the attitudes towards money. 
Sense of security is a predictor of the attitudes towards money. Prediction of the attitude towards money by sense of security is limited.

\section{Conclusions}

The subject of the paper was to analyze the attitudes towards money and selected determinants shaping these attitudes. Particular attention was paid to the socio-demographic and psychological determinant of the attitudes towards money. The study was designed in the way providing the information on the attitudes towards money in adults at the stage of early and middle adulthood, male, and female, employment and unemployment in the Mongolians. The category of psychological variable included: satisfaction with life and sense of security. The results of statistical analysis confirmed some hypotheses partly. The results provided grounds to formulate the following conclusions:

1. First of all, the results confirmed Hypothesis $\mathrm{H} 1$ - the importance of the socio-demographic parameters for the attitude towards money has been partially confirmed in the Mongolian sample;

2. The results confirmed Hypothesis H 2-the impact of the satisfaction with life on the attitude towards money has been partly confirmed in this cultural sample;

3. The end of all, the results confirmed Hypothesis H 3 - the impact of the sense of security on the attitude towards money has been partly confirmed in this cultural sample.

Mongolians think about money as a way to achieve prestige and relatively often them use money as a symbol of power and status. However, men were more inclined to use money to impress and influence others and as a symbol of success than women. They focused on their own financial security issues. Mongolians who have work perceived money as a means which give them security in the future more than unemployed people.

Therefore, Mongolians have tendency to appear hesitant, suspicious, and doubtful in situations related to money. They, after buying something, wondered more often that the some products are cheaper in the other places. The Mongolians spent more to get the very best, the name of the brand products and the most expensive. They viewed money is a source of anxiety as well as a source of protection from anxiety. The results of statistical analysis show that the variable of age is not statistically significant in this study.

Furthermore, there were negative association between satisfaction with life and distrust in the group. It means that hey who have financial worry seem to be less satisfied with their life. Similar result was formulated by Gąsiorowska (2014).

The most number of people in Mongolian sample evaluated own income as average. The percentages of personal professional activity were the highest than another category in the group. The results of statistical analysis showed that differences of frequencies of some components of economic security were significant in the sample. Namely, Mongolians have the highest percentage of possibility of changing job. The most of participants described life future as well. They answered that the most of participants have more debts to family.

The results and above consideration show that the attitude towards money was influenced - in partially different way by psychological and differentiated by socio-demographic parameter, such as gender and employment.

To sum up, important differences exist between the adults living in Mongolia.

I hope that this research will contribute to the preparation the new studies on this issue and important not only for scientists, but also gives psychological knowledge useful also for better the awareness of policy makers in the 
socio-economic problems associated with "money" and psychological mechanisms of economic behavior functioning in different cultures. This knowledge could be useful for reorganization of educational system in such a way that it would better prepare the young generations to effectively manage their financial means. Interestingly, we were able to draw some results on the relation between the structures of the attitudes towards money with the personal developmental stage, in this area, were limited because of the methodological difficulties following from developmental studies in little known cultural contexts moreover subjected to intense transformations. In my point of view, this result can also indicate the independence of the attitudes towards money and its determinants from culture. To some degree, the studies should confirm the biological grounds of personality as the majority of relations between the personal traits and the attitudes towards money occurred in the culture.

\section{Discussion}

The main aim of the author's study was to explore the attitudes towards money among adult Mongolians and explain the differences between them by the differentiation of socio-demographic and psychological determinants. The attitudes toward money were significantly different in the group. According to the first hypothesis, the author found that in the sample, the attitude towards money is differentiated by socio-demographic parameters, such as gender and employment. Earlier studies have pointed out that the attitudes towards money are differentiated by gender (Medina, 1996, Gbadamosi \& Joubert, 2005; Bonsu, 2008). The results revealed that men in both groups were more inclined to use money to impress and influence others, and as a symbol of success than women. These results are consistent with the data from psychological literature. Furnham and Argyle (1998) had found that men are obsessed with money especially for its power-prestige. Men are happier than women with their finances, and feel that they have control over their money (Rubinstein, 1980). Women are more careful with money. Compared to men, they show more concern for future financial security (Bailey \& Gustafson, 1991). The fact of employment or unemployment was significantly reflected statistically in the scale of "Retention-Time" for this sample. The persons scoring high in the subscale "Retention-Time" attach much importance to the stage of preparation to the realization of financial goals, including those related to personal security in the future (Yamauchi \& Templer, 1982). The employed Mongolians treated money as a goal of ensuring security in the future more than the unemployed Mongolians. Therefore, according to Hypothesis H 2, the attitude towards money of the Mongolian group studied depends on general satisfaction with life. More satisfied Mongols have found that money-related situations are provoking their distrust. There were only few studies concerning attitudes towards money and satisfaction with life (Wilhelm, Varcoe, \& Fridrich, 1993, Tang, 2004, Gąsiorowska, 2003). Moreover, according to Hypothesis $\mathrm{H} 3$, the attitude towards money depends on sense of security. The sense of security had the significant negative associations with distrust and anxiety in Mongolian sample. It means that stronger the sense of security, including the attitude towards future and the evaluation of psychological well-being, the less often the individual experiences anxiety in situations with money, and the less often such situations give rise to distrust. These results were confirmed by other studies. For example, Gąsiorowska (2014) wrote that high income might lead to lower level of financial worries both directly. Similar thesis was formulated by Diener and Suh (2000). Having money reduces dependency on others, reducing anxiety in turn (Furnham et al., 2012; Zaleskiewicz, 2004). The predictions of the attitude towards money by feeling security were limited in similar way among the group.

\section{References}

Bandura, A. (1977). Social learning theory. New York: General Learning Press. 
Belk, R. W. (1991). The ineluctable mysteries of possessions. Journal of Social Behavior \& Personality, 6(6), 17-55.

Bonsu, S. M. (2008). Ghanaian attitudes towards money in consumer culture. International Journal of Consumer Studies, 32 , 171-178.

Csikszentmihalyi, M., \& Rochberg-Halton, E. (1981). The meaning of things: Domestic symbols and the self. Cambridge: Cambridge University Press.

Diener, E., Emmons, R. A., Larsen, R. J., \& Griffin, S. (1985). The satisfaction with life. scale. Journal of Personality Assessment, 49, 71-75.

Dogan, V., \& Torlak, O. (2014). The relationship between symbolic money meanings and materialism. Business and Economics Research Journal, 5(2), 1-17.

Fank, M. (1994). The development of a money-handling inventory. Personality and Individual differences, 17, 147-52.

Furnham, A., \& Argyle, M. (1998). The psychology of money. London: Library of Congress Cataloging in Publication Data.

Furnham, A. (1984). Many sides to the coin: The psychology of money usage. Personality and Individual Differences, 5(5), 501-509.

Gąsiorowska, A. (2007). Postawy wobec pieniędzy u rodziców i ich dzieci: O roli pierwotnej socjalizacji ekonomicznej w kształtowaniu stosunku do pieniędzy (Attitudes towards money in parents and their children: The role of primary economic socialization in shaping the relation to money). Psychologia, Edukacja i Spoleczeństwo, 4(3), 245-260.

Gąsiorowska, A. (2013). Money attitudes questionnaire MAQ development and validation of a measurement scale. Polish Journal of Economic Psychology, 3, 20-39.

Gąsiorowska, A. (2014). The relationship between objective and subjective wealth is moderated by financial control and mediated by money anxiety. Journal of Economic Psychology, 43, 64-74.

Gbadamosi, G., \& Joubert, P. (2005). Money ethic, moral conduct and work related attitudes: Field study from the public sector in Swaziland. Journal of Management Development, 24(8), 754-763

Górnik-Durose, M. (2002). Psychologiczne aspekty posiadania-międzyinstrumentalnościa a spoteczna użyteczniścia dóbr Materialnych (Psychological aspects of ownership-between instrumental and social utility of material goods). Katowice: Wydawnictwo Uniwersytet Śląski.

Górnik-Durose, M., \& Pilch, I. (2016). The dual nature of materialism. How personality shapes materialistic value orientation. Journal of Economic Psychology, 57, 102-116.

Janusz, C. (1991). Ekonomia szczęścia i psychologia bogactwa (Economics of happiness and psychology of wealth). NAUKA, $1 / 2012,51-88$

Kahneman, D. \& Deaton, A. (2010). High income improves evaluation of life but not emotional well-being. Proceedings of the National Academy of Sciences, 107(38), 16489-16493.

Kirkcaldy, B., \& Furnham, A. (1993). Predictors of beliefs about money. Psychological Reports, 73(3), 1079-1082.

Lynn, M. (1991). Restaurant tipping: A reflection of customers' evaluations of a service? Journal of Consumer Research, 18, 438-448

Medina, J. F. (1996). Comparison of Mexican-American and Anglo-American attitudes towards money. Journal of Consumer Affairs, 30(1), 124-144.

Merchant, A. (2016). Cross-cultural folk-tale-elicitation research on the perceived power, humanistic and religious symbolisms, and use of money. Journal of Business Research, 10, 21.

Myers, D. (2004). Exploring psychology (6th ed., in Modules). New York: Worth publishers.

Paszkowska-Rogacz, A. (2015). Career patterns in the family of origin and marital satisfaction among young couples. In R. Tomaszewska- Lipiec (Reed.), Work-personal life: Between harmony and disintegration (pp. 69-88). Kraków: Impuls. ISBN: 978-83-7850-985

Rubinstein, C. (1980). Your money and your life. Psychology Today, 12, 47-58.

Smith, A. (1776). The wealth of nation (Reprint edition in 1937). (E. Cannan [Ed.], 1904). New York: Modern Library.

Tang, H. (2004). A universal evolutionary index for amino acid changes. Mol Biol Evol, 21 (8), 1548-1556.

Tang, T. L. P. (1992). The meaning of money: Extension and exploration of the money ethic scale in a sample of university students in Taiwan. Journal of Organizational Behavior, 14, 93-94.

Tang, T., \& Gilbert, T. (1995). Attitudes toward money as related to intrinsic and extrinsic job satisfaction, stress and work-related attitudes. Personality and Individual Differences, 19, 327-333.

Tumendemberel, P., Liberska, H., \& Deja, M. (2018). Mongolian adaptation of Money Attitude Scale (MAS). Article sent to the editor. 
Tumendemberel, P. (2017). Social psychology: The attitude towards money among adult people and their selected determinants - cross-cultural study (Doctoral dissertation, University of Karzimiez Wielki, Poland).

Wąsowicz-Kiryło, G. (2013). Postawy wobec pieniędzy: Pomiar-struktura-determinanty (Attitudes towards money: Measurement-structure-determinants). Warszawa: Difin.

Wernimont, P. F., \& Fitzpatrick, S. (1972). The meaning of money. Journal of Applied Psychology, 56(3), 218-226.

Weitzel, W. (1977). Predicting pay satisfaction from non-pay work variables. Journal of Economy and Society, 16(3), 323-334.

Yamauchi, K., \& Templer, D. (1982). The development of a Money Attitude Scale. Journal of Personality Assessment, 46, 522-528.

Zaleskiewicz, T. (2004). Psychologia pieniądza (Psychology of money). Gdańsk: Gdańskie Wydawnictwo Psychologiczne.

Zotova, O. Y. (2011). The need for security with different social and economic groups representatives. Moscow University Journal of Psychology, 14(4), 90. 